\title{
A Novel Resveratrol Tetramer Vaticanol C from Stem Bark Acts as an Anti- metastatic Action in a Mouse Mammary Cancer Model
}

\author{
Masa-Aki Shibata $^{1^{*}}$, Yukihiro Akao $^{2}$ and Munekazu linuma ${ }^{3}$ \\ ${ }^{1}$ Laboratory of Anatomy and Histopathology, Graduate School of Health Sciences, Osaka Health Science University, Japan \\ 2 United Graduate School of Drug Discovery and Medical Information Science, Gifu University, Gifu, Japan \\ ${ }^{3}$ Gifu Pharmaceutical University, Gifu, Japan
}

*Corresponding author: Shibata MA, Laboratory of Anatomy and Histopathology, Graduate School of Health Sciences, Osaka Health Science University, 1-9-27 Temma, Kita-ku, Osaka, 530-0043, Japan, Tel: +81-6-7506-9046; Fax: +81-6-6352-5995; E-mail: masaaki.shibata@ohsu.ac.jp

Rec date: Mar 16, 2015; Acc date: Mar 18, 2015; Pub date: Mar 22, 2015

Copyright: (C) 2015 Shibata MA, et al. This is an open-access article distributed under the terms of the Creative Commons Attribution License, which permits unrestricted use, distribution and reproduction in any medium, provided the original author and source are credited.

\section{Editorial}

Plants and plant extracts have been traditionally used in Ayuvedic and Chinese medicine for many centuries. A large number of natural products appear to have strong therapeutic effects and the discovery of new plants with potential biological activities is a passionate endeavor for many concerned with natural medicinal. Among those already investigated, great attention has been paid to polyphenols because of their antioxidant and possible antitumor properties [1], including $\alpha-$ and $\gamma$-mangostin from the mangosteen pericarp [2-4] and resveratrol. Resveratrol, a chemo preventive and therapeutic polyphenol found in grape skin and dipterocarpaceous plants [5], is one of the most famous phytochemical compounds currently under investigation. Several studies have shown that resveratrol actually possesses multiple biological activities ranging from anti-tumor functions [6] to prevention of heart disease [7].

Isolated from the stem bark of Vatica rassak in Dipterocarpacea, the resveratrol tetramer vaticanol $\mathrm{C}$ has shown induction of apoptotic cell death and suppression of cell proliferation in various human cancer cells [8], suggesting anti-tumoral effects. We recently demonstrated anti-metastatic effects of vaticanol $C$ [9] in a mouse metastatic mammary cancer model carrying a p53 mutation, a model which demonstrates a metastatic spectrum similar to that seen in human breast cancers $[4,10]$. Here, we introduced the summary of the results on anti-metastatic abilities of vaticanol $\mathrm{C}$ in vitro and in vivo experiments [9].

Vaticanol C induced in vitro apoptosis, as evaluated by morphological changes, nucleosomal DNA fragmentation, and elevated activities of caspases (which are executional factors of apoptosis); similarly, apoptosis was significantly increased in vivo in mammary tumor cells exposed to $200 \mathrm{ppm}$ dietary vaticanol C. Although tumor growth was similar between the control and vaticanol C-treated groups, the multiplicities of lymph node and lung metastasis were significantly reduced only in animals receiving the highest dose (200 ppm) of vaticanol C; overall metastasis to any organ also decreased, but not to a statistically significant degree over control. Cell proliferation rates tended to decrease in mammary tumors with exposure to vaticanol $\mathrm{C}$ in a dose-dependent manner but, again, the decrease was not statistically significant. Breast cancer is one of the most lethal cancers in humans, and death is largely due to metastasis, usually to lungs, lymph node, liver, and bone. Since lymph node involvement is the most important prognostic factor in breast cancer patients, the anti-metastatic activity of vaticanol $\mathrm{C}$ may be of clinical significance.
Angiogenesis in mammary tumors tended to be lower in vaticanol C-treated groups. Furthermore, the numbers of dilated lymphatic vessels having intraluminal cancer cells (an indication of lymphatic invasion) in mammary tumors were significantly decreased with administration of vaticanol $\mathrm{C}$, indicating a reduction in tumor cell migration - at least, by the lymphatic route. The most common pathway of initial dissemination of many solid malignancies is via the lymphatics, with varying metastasis was found in human cancer [11].

Vaticanol $\mathrm{C}$ has been shown to induce apoptosis via p53-dependent pathways in a variety of cancer cells [8]. In the colon cancer cell line SW480, which carries a p53 mutation, vaticanol C induces apoptosis but reduces the transcriptional levels of mutant p53, suggesting transcriptional modulation. In the case of non-functional mutant p53, the p73 homolog may act as an apoptotic inducer. Since half of human cancers are reported to have p53 mutations [12], the fact that vaticanol $\mathrm{C}$ induces an apoptotic response in the presence of mutant p53 may be highly relevant to inhibiting many human cancers.

\section{References}

1. Yang CS, Landau JM, Huang MT, Newmark HL (2001) Inhibition of carcinogenesis by dietary polyphenolic compounds. Annu Rev Nutr 21: 381-406.

2. Akao Y, Nakagawa Y, Iinuma M, Nozawa Y (2008) Anti-cancer effects of xanthones from pericarps of mangosteen. Int J Mol Sci 9: 355-370.

3. Doi H, Shibata MA, Shibata E, Morimoto J, Akao Y, et al. (2009) Panaxanthone isolated from pericarp of Garcinia mangostana L. suppresses tumor growth and metastasis of a mouse model of mammary cancer. Anticancer Res 29: 2485-2495.

4. Shibata MA, Iinuma M, Morimoto J, Kurose H, Akamatsu K, et al. (2011) a-Mangostin extracted from the pericarp of the mangosteen (Garcinia mangostana Linn) reduces tumor growth and lymph node metastasis in an immunocompetent xenograft model of metastatic mammary cancer carrying a p53 mutation. BMC Med 9: 69.

5. Tanaka T, Ito T, Nakaya K, Iinuma M, Riswan S (2000) Oligostilbenoids in stem bark of Vatica rassak. Phytochemistry 54: 63-69.

6. Jang M, Cai L, Udeani GO, Slowing KV, Thomas CF, et al. (1997) Cancer chemopreventive activity of resveratrol, a natural product derived from grapes. Science 275: 218-220.

7. Hung LM, Chen JK, Huang SS, Lee RS, Su MJ (2000) Cardioprotective effect of resveratrol, a natural antioxidant derived from grapes. Cardiovasc Res 47: 549-555.

8. Ito T, Akao Y, Yi H, Ohguchi K, Matsumoto K, et al. (2003) Antitumor effect of resveratrol oligomers against human cancer cell lines and the molecular mechanism of apoptosis induced by vaticanol C. Carcinogenesis 24: 1489-1497.

9. Shibata MA, Akao Y, Shibata E, Nozawa Y, Ito T, et al. (2007) Vaticanol $\mathrm{C}$, a novel resveratrol tetramer, reduces lymph node and lung metastases 
Citation: Shibata MA, Akao Y, linuma M (2015) A Novel Resveratrol Tetramer Vaticanol C from Stem Bark Acts as an Anti-metastatic Action in a Mouse Mammary Cancer Model . Altern Integ Med 4: e118. doi:10.4172/2327-5162.1000e118

Page 2 of 2

of mouse mammary carcinoma carrying p53 mutation. Cancer Chemother Pharmacol 60: 681-691.

10. Shibata MA, Ambati J, Shibata E, Albuquerque RJ, Morimoto J, et al. (2010) The endogenous soluble VEGF receptor-2 isoform suppresses lymph node metastasis in a mouse immunocompetent mammary cancer model. BMC Med 8: 69.

11. Currie MJ, Hanrahan V, Gunningham SP, Morrin HR, Frampton C, et al. (2004) Expression of vascular endothelial growth factor D is associated with hypoxia inducible factor (HIF-1alpha) and the HIF-1alpha target gene DEC1, but not lymph node metastasis in primary human breast carcinomas. J Clin Pathol 57: 829-834.

12. Greenblatt MS, Bennett WP, Hollstein M, Harris CC (1994) Mutations in the p53 tumor suppressor gene: clues to cancer etiology and molecular pathogenesis. Cancer Res 54: 4855-4878. 